\title{
Prevalence, geographic distribution, and geographic variability of major cardiovascular risk factors in Spain: pooled analysis of data from population-based epidemiological studies: the ERICE study
}

\author{
Rafael Gabriela, Margarita Alonso, Antonio Segura, María J. Tormo, Luis M. Artigao, \\ José R. Banegas, Carlos Brotons, Roberto Elosua, Arturo Fernández-Cruz, Javier \\ Muñiz, Blanca Reviriego, Fernando Rigo, on behalf of the ERICE Cooperative Group
}

\begin{abstract}
Introduction and objectives. To determine the prevalence and geographic distribution of major cardiovascular risk factors in the Spanish population. To investigate whether geographic variability exists.

Methods. Data were pooled from eight cross-sectional epidemiologic studies carried out in Spain between 1992 and 2001 whose methodological quality satisfied predefined criteria. Individual data were reassessed and analyzed by age group (20-44 years, 45-64 years, and [.greaterequal] 65 years), sex, and geographic area. The study population included 19729 individuals. Mean values and unadjusted and adjusted prevalence rates were derived for various risk factors.

Results. The most common cardiovascular risk factors in the Spanish population were, in descending order: hypercholesterolemia (ie, total cholesterol $>200 \mathrm{mg} / \mathrm{dL}$ ) in $46.7 \%$, hypertension in $37.6 \%$, smoking in $32.2 \%$, obesity in $22.8 \%$, and diabetes mellitus in $6.2 \%$. The mean values for blood pressure, body mass index, high-density lipoprotein cholesterol, and glycemia varied considerably with age, sex, and geographic area. The highest levels of cardiovascular risk factors were observed in Mediterranean and south-eastern areas of the country and the lowest, in northern, and central areas.

Conclusions. The prevalence of major cardiovascular risk factors in Spain was high. Their distribution varied considerably with geographic area.
\end{abstract}

\begin{abstract}
Resumen
Introducción y objetivos. Estimar la prevalencia y la distribución geográfica de los principales factores de riesgo cardiovascular en la población española. Investigar la existencia de diferencias geográficas.

Métodos. Agregación de ocho estudios epidemiológicos transversales, realizados en España entre 1992 y 2001, que superaron criterios de calidad metodológica. Reanálisis conjunto de los datos individuales por grupos de edad (20-44, 45-64 y [.greaterequal] 65 años), sexo y grandes áreas geográficas. Población de estudio: 19.729 sujetos. Estimación de valores medios y prevalencias crudas y ajustadas.

Resultados. Por orden decreciente, los factores de riesgo cardiovascular más frecuentes en la población española fueron la hipercolesterolemia (colesterol total > $200 \mathrm{mg} / \mathrm{dl}, 46,7 \%$ ), hipertensión arterial (37,6\%), tabaquismo $(32,2 \%)$, obesidad $(22,8 \%)$ y diabetes mellitus $(6,2 \%)$. Los valores medios de presión arterial, índice de masa corporal, colesterol de las lipoproteínas de alta densidad y glucemia varían ampliamente con la edad, el sexo y las áreas geográficas. La mayor carga de factores de riesgo cardiovascular se observa en las zonas sureste y mediterránea y la menor, en las áreas norte y centro.

Conclusiones. En España la prevalencia de los principales factores de riesgo cardiovascular es elevada. Hay marcadas diferencias geográficas en su distribución.
\end{abstract}

Key words Epidemiology; Cardiovascular risk factors; Geographic variability; Spain

Palabras clave Epidemiología; Factores de riesgo cardiovascular; Diferencias regionales; España

Abbreviations BMI, body mass index; BP, blood pressure; CVRF, cardiovascular risk factor; DM, diabetes mellitus; HCT, hypercholesterolemia; HT, hypertension; TC, total cholesterol concentration 


\section{Introduction}

Ischemic heart disease accounts for $32 \%$ of all cardiovascular deaths in Spain. This percentage is higher among men $(40 \%)$ than among women $(24 \%){ }^{1}$

Knowledge of the main modifiable cardiovascular risk factors (CVRFs) in ischemic heart disease allows cardiovascular prevention strategies to be drawn up and implemented. The classic modifiable CVRFs are smoking, hypertension, hypercholesterolemia, and diabetes mellitus (DM). Different authors have indicated that coronary artery disease can occur in up to $50 \%$ of cases in the absence of these CVRFs, ${ }^{2,3}$ but recent studies show that the classic CVRFs are determinant. ${ }^{4-7}$ Therefore, studies of prevalence of CVRFs are still justified to generate hypotheses and define health policies for cardiovascular prevention.

In Spain, several epidemiologic studies have been performed on CVRFs. A recent metaanalysis ${ }^{8}$ identified 47 cross-sectional studies in Spain published between 1990 and 2003, with a total of 130945 patients. Although cross-sectional studies are available for different geographic areas of Spain, to date, no pooling of individual data on the participants had been performed for these studies.

The objective of this study was to estimate the distribution of body mass index (BMI), blood pressure (BP), fasting blood glucose, total cholesterol concentration (TC), and high-density lipoprotein cholesterol (HDL-C) concentration, and to estimate the prevalence of hypertension, hypercholesterolemia, DM, smoking, and obesity by age-sex groups and geographic area. To do this, data from different crosssectional studies with similar methodology conducted between 1992 and 2001 were pooled and analyzed.

\section{Methods}

Data Sources

A joint database was created with the individual data from all subjects participating in 8 cross-sectional epidemiologic studies performed by participating nodes of the ERICE network (Appendix, Table 1). ${ }^{9-16}$

Table 1. Characteristics of the Original Studies Included in the ERICE Study

\begin{tabular}{|c|c|c|c|c|c|c|}
\hline \multirow[t]{2}{*}{ Study } & \multirow[t]{2}{*}{ Place, Scope (Environment), y } & \multirow[t]{2}{*}{ Sampling Method } & \multicolumn{3}{|c|}{ Population } & \multirow{2}{*}{$\begin{array}{l}\text { Age } \\
\text { Group, } \\
\text { y }\end{array}$} \\
\hline & & & Men & Women & Total & \\
\hline EPICARDIAN $^{9}$ & $\begin{array}{l}\text { Madrid, Lugo, Arévalo (R/U) } 3 \\
\text { districts; } 1994\end{array}$ & $\begin{array}{l}\text { Random, stratified by age and } \\
\text { sex }\end{array}$ & 1628 & 2121 & 3749 & $>65$ \\
\hline VIVA $^{10}$ & $\begin{array}{l}\text { Arévalo, Talavera, Guadalajara, } \\
\text { Lugo, Avilés, Vic, Alicante, Mérida, } \\
\text { Pizarra (R/U), } 9 \text { municipalities; } 1996\end{array}$ & $\begin{array}{l}\text { Random, stratified by age, sex, } \\
\text { and municipality }\end{array}$ & 1341 & 1602 & 2943 & $35-64$ \\
\hline HORA $^{11}$ & Spain (R/U), national; 2001 & $\begin{array}{l}\text { Random sample, multiple age } \\
\text { groups, pooled }\end{array}$ & 1452 & 2564 & 4016 & $>60$ \\
\hline REGICOR $^{12}$ & Gerona (R), district; 1997 & $\begin{array}{l}\text { Two age groups, stratified by } \\
\text { size of population, age, sex }\end{array}$ & 838 & 910 & 1748 & $25-74$ \\
\hline CORSAIB $^{16}$ & Majorca (R/U), provincial; 1999 & Random multiple age groups & 814 & 871 & 1685 & $35-74$ \\
\hline Talavera $^{14}$ & Talavera (R/U), district; 1995 & $\begin{array}{l}\text { Random multiple age groups } \\
\text { stratified by size of } \\
\text { municipalities, age, and sex }\end{array}$ & 630 & 703 & 1333 & $25-74$ \\
\hline GEVA $^{13}$ & Albacete (R/U), provincial; 1996 & Two age groups with pooling & 612 & 710 & 1322 & $>18$ \\
\hline Murcia $^{15}$ & Murcia (R/U), regional; 1992 & $\begin{array}{l}\text { Random, stratified by sex, age, } \\
\text { type of residence, and health } \\
\text { area, and pooled by municipality }\end{array}$ & 1514 & 1577 & 3091 & $18-65$ \\
\hline
\end{tabular}

Environment indicates national, regional, provincial, district, municipal; R, rural environment; R/U, rural and urban environment. 
The studies included met the following criteria:

- Single or multicenter studies done in Spain between 1992 and 2001, which included a general adult population of both sexes aged over 20 years, with more than 1 age group

- Selection of the participants by random sampling, with a description of the target population, the sampling method, rate of participation, and an acceptable description of the statistical methods used (prespecified sample size, statistical power of the study, and level of precision of the estimates)

- Use of standardized and validated measurement methods for the primary outcome measures of the study (BP, lipid profile, weight, height, smoking, blood glucose)

- All the studies, except the HORA study, took a fasting blood sample (at least 10 hours without food) with measurement of the lipid fractions (TC, HDL-C), and blood glucose levels

\section{Variables Studied and Definition of Cardiovascular Risk Factors}

The final joint database included the following study variables: study characteristics (date of data collection, sampling method, and rate of participation), sociodemographic data (age, sex, and place of residence), anthropometric variables (weight and height), BP and heart rate, cigarette consumption, laboratory data (TC, HDL-C, and fasting blood glucose), and personal history of stroke, ischemic heart disease, hypertension, hypercholesterolemia, diabetes, and pharmacologic treatment of these conditions.

Hypertension was classed as systolic BP $\geq 140 \mathrm{~mm} \mathrm{Hg}$ or diastolic BP $\geq 90 \mathrm{~mm} \mathrm{Hg}$, or treatment with antihypertensive agents. ${ }^{17} \mathrm{DM}$ was defined when venous blood glucose levels in fasting conditions were greater than $126 \mathrm{mg} / \mathrm{dL}$ or the subject was being treated with oral antidiabetic agents or insulin. ${ }^{18}$ Two criteria for hypercholesterolemia were considered: TC concentration $\geq 200 \mathrm{mg} / \mathrm{dL}$ or treatment with lipid-lowering agents and TC $\geq 250 \mathrm{mg} / \mathrm{dL}$ or treatment with lipid-lowering agents. ${ }^{19}$ Body mass index (BMI) was calculated for each individual using the formula of weight in kilograms divided by the square of height in meters, and obese patients were considered those with a BMI $\geq 30 .{ }^{20}$ A regular smoker was considered to be one who smoked 1 cigarette per day or 5 per week in the last year, an occasional smoker was one who smoked 4 cigarettes or less per week, and an ex-smoker was someone who had not smoked a cigarette in the last year. ${ }^{21}$

\section{Data Analysis}

Before entering the data, an analysis of homogeneity among the different studies was undertaken. This was done by checking the heterogeneity by age and sex of the variances of the main variables, using the Levene test for equality of variances or the analysis of variance (ANOVA) according to whether 2 or more studies contributed to the estimation of the given variable. Homogeneity was not accepted for variables with $P<.05$, and data with significant heterogeneity were discarded.

To guarantee sufficient statistical power for the estimators by geographic area, 4 large areas were defined that grouped together different autonomous regions: North (Galicia, Asturias, Aragon, Basque Country, Navarre, La Rioja), Mediterranean (Balearics, Catalonia, Valencia), Center (Castile-La Mancha, Castile-León, Madrid, Extremadura), and South-East (Andalusia and Murcia). Age and sex groups with fewer than 30 individuals represented in a given geographic area were discarded.

For description of the selected data, basic statistics for central tendency were used-arithmetic mean with standard deviation (SD) when the variables were considered continuous and relative frequency distribution (prevalence) and their 95\% confidence intervals (CI) when these variables were considered categoric, by age groups (20-44 years, $45-64$ years, and $\geq 65$ years), and sex.

For comparison of measures, the Student-Fisher $t$ test was used in the case of independent binary measures and analysis of variance for variables of more than 2 categories. To quantify the size of the difference in prevalences of the CVRFs among geographic areas, the ratio of prevalences was used, taking as reference the lowest value for each factor.

For comparison among geographic areas, the prevalence of the different CVRF, the rates were adjusted using the direct method, using the general Spanish population in 2006 as the standard population. ${ }^{22}$ 


\section{Results}

\section{Sociodemographic Characteristics of the Study Population}

The analysis of homogeneity between studies did not show significant differences between the different variables in most of the age and sex groups, and so the data could be pooled without affecting the internal validity. Heterogeneity was only observed in some of the least well represented age and sex groups: for BMI in those under 45 years old ( $P=.01)$, for diastolic BP in those aged over 65 years $(P=.038)$, and for TC in women under 45 years old $(P=.04)$.

The final sample for analysis comprised 19729 subjects with full information for all the aforementioned variables. Table 2 shows the distribution by age, sex, and large geographic areas of the sample analyzed. The mean (SD) age was 57.6 (17.02) years, and 55.5\% of participants were women and $42.5 \%$ were over 65 years of age. Differences were observed in the distribution by age and sex between geographic areas $(P=.01)$.

Table 2. Distribution of the Study Population by Age, Sex, and Geographic Area

\begin{tabular}{|c|c|c|c|c|c|c|c|c|}
\hline & \multicolumn{6}{|c|}{ Age Group, y } & \multicolumn{2}{|c|}{ Total } \\
\hline & \multicolumn{2}{|c|}{$20-44$} & \multicolumn{2}{|c|}{$45-64$} & \multicolumn{2}{|c|}{$\geq 65$} & \multirow[b]{2}{*}{$\%$} & \multirow[b]{2}{*}{ No. } \\
\hline & $\%$ & No. & $\%$ & No. & $\%$ & No. & & \\
\hline \multicolumn{9}{|l|}{ Population } \\
\hline Women & 13.6 & 2683 & 17.3 & 3412 & 24.6 & 4855 & 55.5 & 10950 \\
\hline Total & 26.1 & 5148 & 31.4 & 6194 & 42.5 & 8383 & 100 & 19729 \\
\hline North & 7.4 & 179 & 22.8 & 554 & 69.8 & 1698 & 12.3 & 2431 \\
\hline Mediterranean & 26.3 & 1383 & 42.9 & 2259 & 30.8 & 1618 & 26.7 & 5260 \\
\hline Center & 18.3 & 1403 & 25.5 & 1956 & 56.2 & 4319 & 38.9 & 7678 \\
\hline South-east & 50.2 & 2187 & 32.7 & 1425 & 17.2 & 648 & 22.1 & 4360 \\
\hline
\end{tabular}

Distribution of Mean BMI, Systolic BP, Diastolic BP, Blood Glucose, TC, and HDL-C by Age, Sex, and Geographic Area

The mean of all CVRFs considered, except HDL-C, increased with age (Figures 1 to 4 ). This increase was observed in all age groups for systolic BP and in both sexes for blood glucose, and only in women for TC. Other factors such as BMI, diastolic BP, and TC in men increased up to 65 years and then leveled off or decreased slightly.

Blood sugar levels were greater in men than in women for all age groups and geographic areas, and the highest levels of HDL-C were observed in women. Women had lower levels than men for all risk factors up to 45 years of age, except for the aforementioned HDL-C levels. Above this age, the mean values of CVRFs were similar to those of men, and even exceeded them at ages over 65 years for BMI and TC.

By geographic area, the south-east region had the highest levels of systolic BP, HDL-C, BMI (only in those aged over 45 years) $(P<.001)$, and significantly lower values of TC $(P<.001)$, whereas blood glucose levels were slightly higher in the Mediterranean region. 


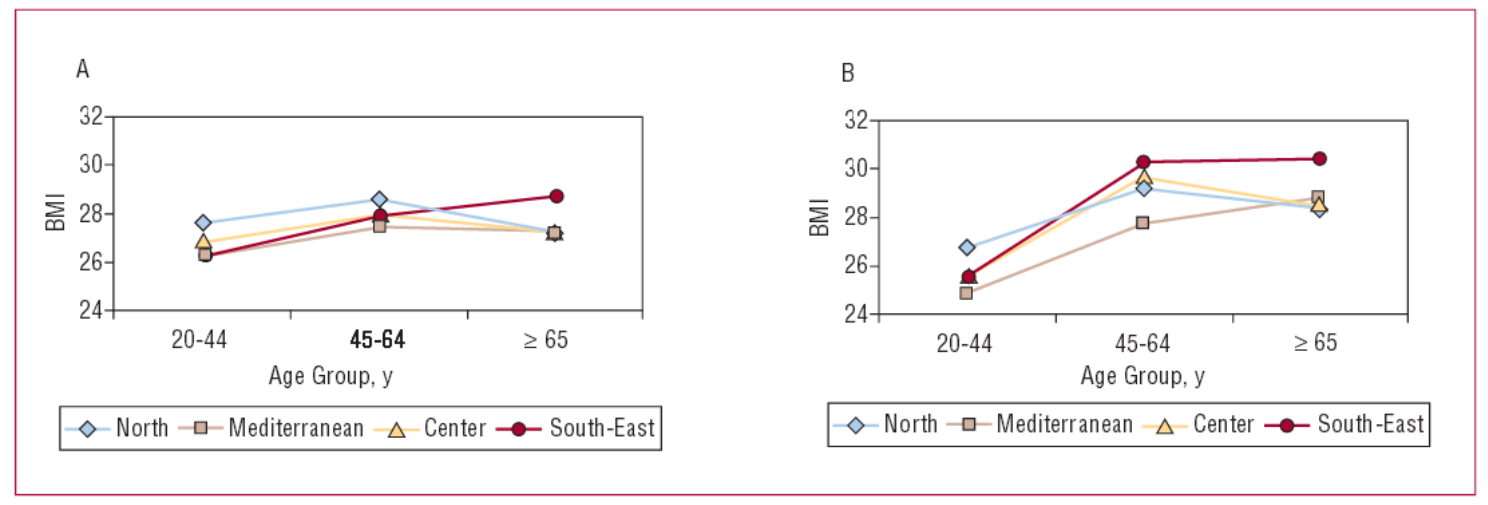

Figure 1. Distribution of the mean values of body mass index (BMI) by sex, age, and geographic area. A: men. B: women

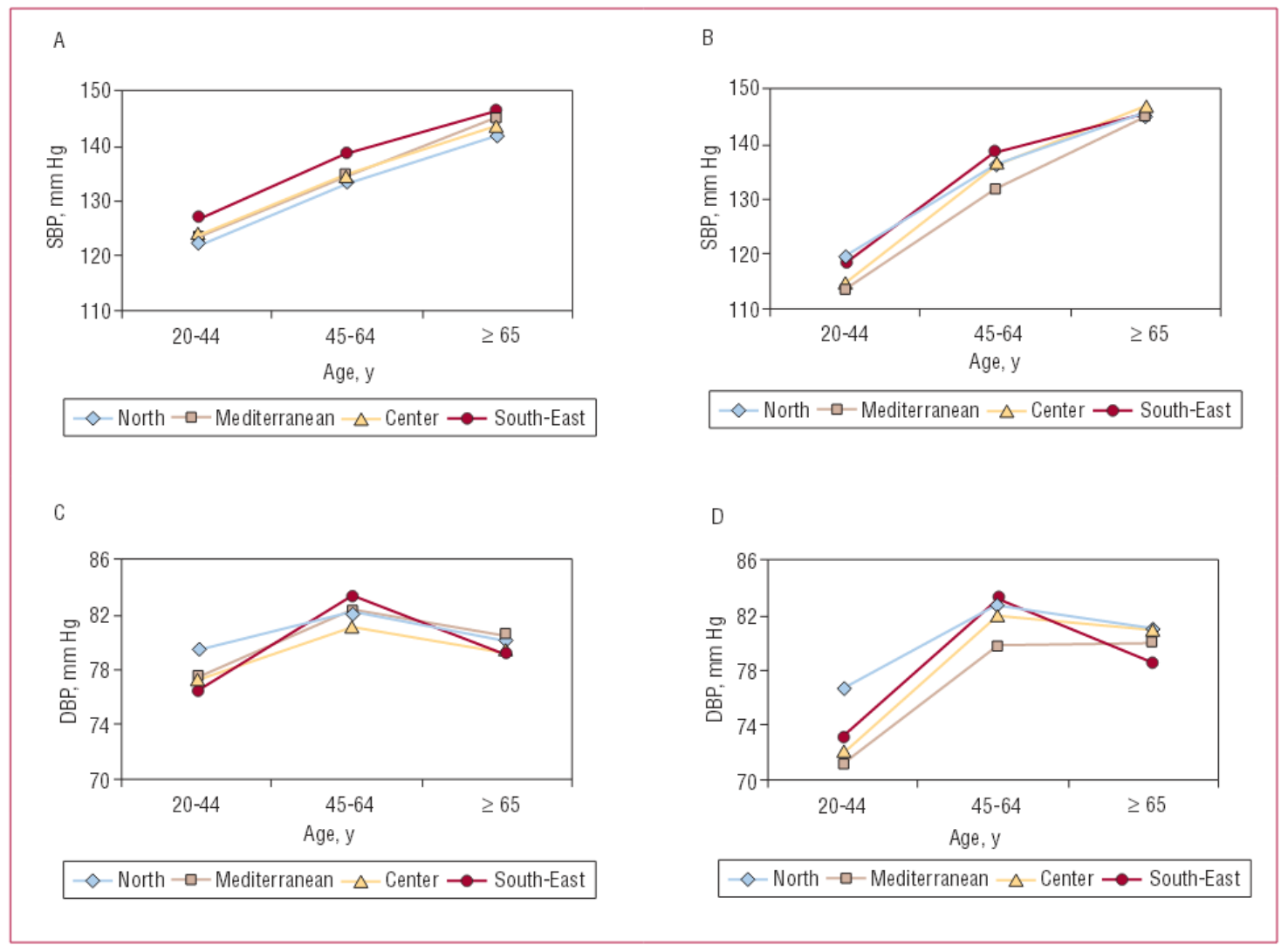

Figure 2. Distribution of the mean systolic blood pressures (SBP) and diastolic blood pressures (DBP) by sex, age, and geographic area. A: SBP for men. B: SBP for women. C: DBP for men. D: DBP for women. 


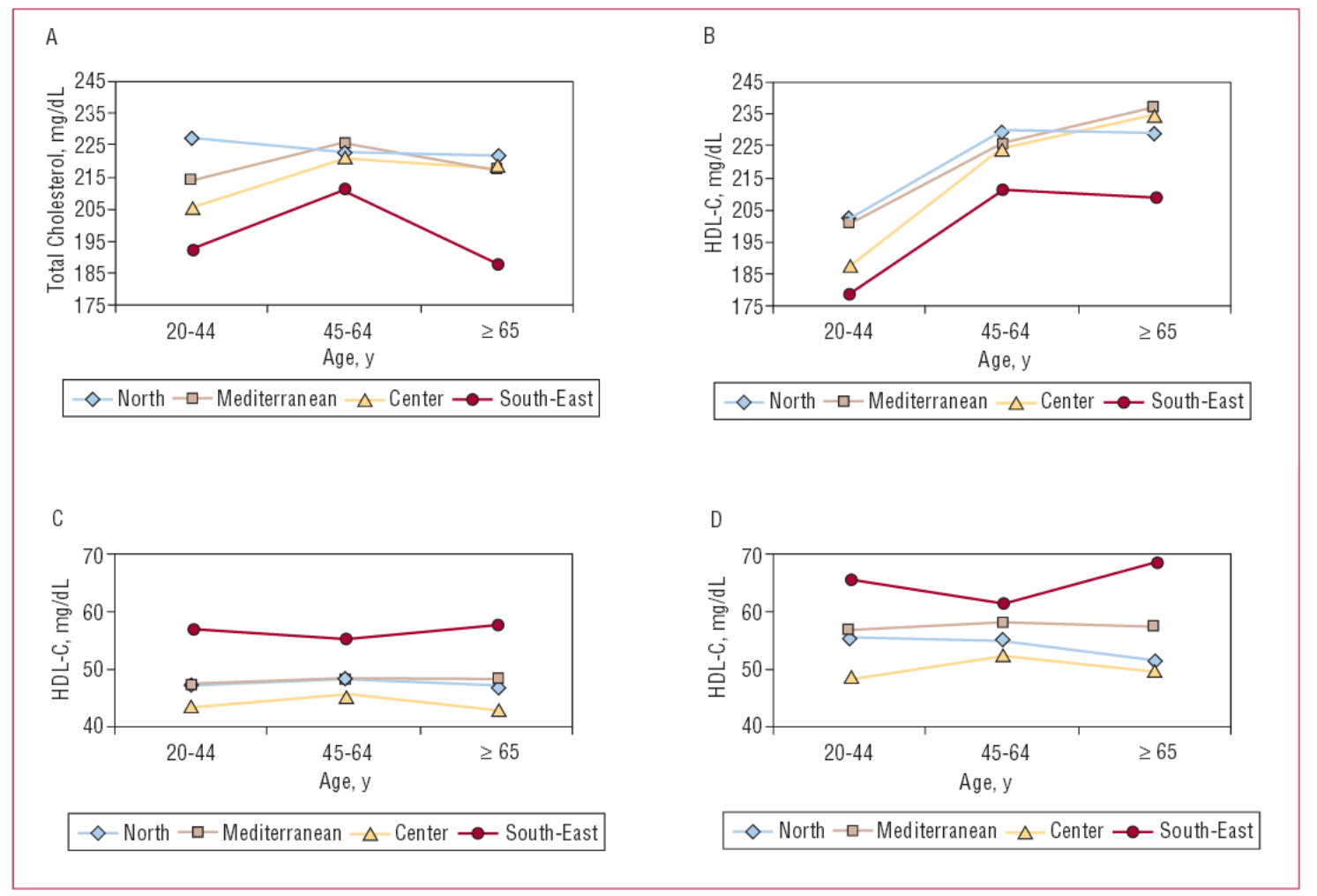

Figure 3. Distribution of the mean of total cholesterol and high-density lipoprotein cholesterol (HDL-C) concentrations by sex, age, and geographic area. A: total cholesterol of men. B: total cholesterol of women. C: HDL-C of men. D: HDL-C of women

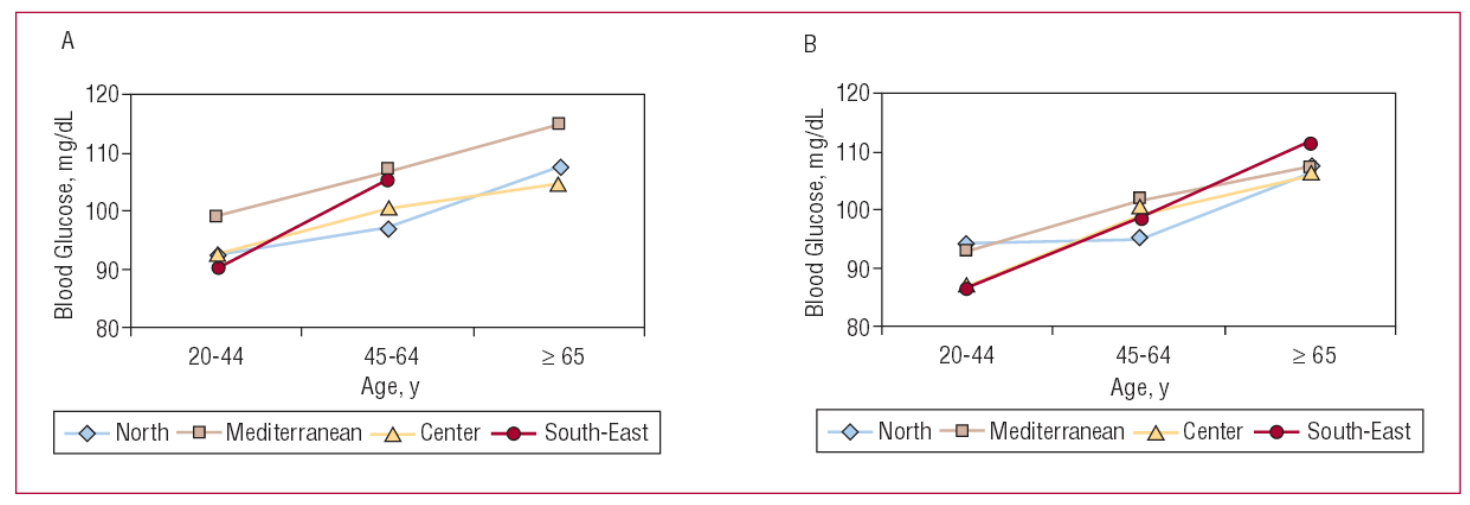

Figure 4. Distribution of mean blood glucose levels by sex, age, and geographic area. A: men. B: women

\section{Prevalence of CVRFs by Age, Sex, and Geographic Area}

Table 3 shows the unadjusted prevalences of the different CVRFs in each age and sex group. The prevalences of hypertension and DM increased progressively with age in both sexes. This was not the case for hypercholesterolemia and obesity, in which stabilization or even a slight decrease after 65 years occurred. In contrast, smoking was most prevalent among younger participants and tended to decrease significantly with age, above all in women. In the 20-44-year-old age group, all CVRFs were more prevalent in men than in women. In the 45-64-year-old age group, except for smoking and DM, which were more prevalent among men, women tended to be more obese (35.1\% vs $24.8 \%)$ and had similar levels of hypercholesterolemia and hypertension to men. For those older than 65 years, in contrast, the prevalence of risk factors, except for smoking, was greater in women than in men. 
Table 3. Unadjusted Prevalences by Age and Sex of the Different Cardiovascular Risk Factors

\begin{tabular}{|c|c|c|c|c|c|c|c|c|}
\hline & \multicolumn{6}{|c|}{ Age Group, y } & \multicolumn{2}{|r|}{ Sex } \\
\hline & \multicolumn{2}{|r|}{$<45$} & \multicolumn{2}{|c|}{$45-64$} & \multicolumn{2}{|r|}{$\geq 65$} & & \\
\hline & $\%$ & $95 \% \mathrm{CI}$ & $\%$ & $95 \% \mathrm{CI}$ & $\%$ & $95 \% \mathrm{CI}$ & $\%$ & $95 \% \mathrm{CI}$ \\
\hline \multicolumn{9}{|c|}{ Smoking $(n=19654)$} \\
\hline Men & 53.7 & $51.7-55.7$ & 38.6 & $36.8-40.5$ & 21.3 & $19.9-22.7$ & 35.9 & $34.9-36.9$ \\
\hline Women & 40.4 & $38.5-42.3$ & 6.5 & $5.7-7.4$ & 2.5 & $2.1-3$ & 13 & $12.4-13.7$ \\
\hline \multicolumn{9}{|c|}{ Obesity ( $\mathrm{n}=19729)$} \\
\hline Men & 15.9 & $14.4-17.4$ & 26.5 & $24.8-28.2$ & 22.5 & $21.1-23.9$ & 21.9 & $21-22.8$ \\
\hline Women & 13.3 & $12.1-14.7$ & 36.7 & $35.1-38.4$ & 34.8 & $33.4-36.1$ & 30.1 & 29.3-31 \\
\hline \multicolumn{9}{|c|}{ Hypercholesterolemia $(\mathrm{TC}>250 \mathrm{mg} / \mathrm{dL})(\mathrm{n}=15713)$} \\
\hline Men & 14.1 & $12.7-15.5$ & 24.3 & $22.7-25.9$ & 18.7 & $17.4-20$ & 19.2 & $18.3-20$ \\
\hline Women & 6.1 & $5.2-7$ & 24.6 & $23.2-26.1$ & 26 & $24.8-27.3$ & 20.7 & $19.9-21.5$ \\
\hline \multicolumn{9}{|c|}{ Hypercholesterolemia (TC >200 mg/dL) $(\mathrm{n}=15713)$} \\
\hline Men & 45.1 & $43.1-47.1$ & 59.8 & $57.9-61.6$ & 43.7 & $42-45.3$ & 49.2 & $48.1-50.2$ \\
\hline Women & 32.9 & $31.1-34.7$ & 59.6 & $57.9-61.3$ & 48.1 & $46.7-49.5$ & 48 & $47-48.9$ \\
\hline \multicolumn{9}{|c|}{ Hypertension $(\mathrm{n}=19729)$} \\
\hline Men & 22.5 & $20.8-24.2$ & 49 & $47-50.8$ & 66.4 & $64.9-68$ & 48.5 & $47.5-49.6$ \\
\hline Women & 10.3 & $9.2-11.5$ & 50.3 & $48.6-52$ & 74.1 & $72.8-75.3$ & 51 & $50.1-52$ \\
\hline
\end{tabular}

TC indicates total cholesterol.

Table 4 shows the adjusted prevalences of the different CVRFs. The most common CVRFs in the Spanish population were, in descending order: hypercholesterolemia (46.7\%) taken as TC $>200 \mathrm{mg} / \mathrm{dL}$, hypertension (37.6\%), smoking (32.2\%), obesity (22.8\%), and finally DM (6.2\%). If we use the cutoff for TC of $250 \mathrm{mg} / \mathrm{dL}$, the prevalence of hypercholesterolemia drops to fourth place $(17.1 \%)$.

By geographic area, the highest adjusted prevalences (Table 4) were observed for smoking (34.2\%), hypertension $(42 \%)$, and obesity $(26.5 \%)$ in the south- east regions; obesity was also very frequent in the northern regions $(26.8 \%)$. Diabetes mellitus (7.8\%) and hypercholesterolemia $(54.8 \%$ with TC $>200$ $\mathrm{mg} / \mathrm{dL}$ and $20 \%$ with $\mathrm{TC}>250 \mathrm{mg} / \mathrm{dL}$ ) were more frequent in the Mediterranean area.

The prevalence ratios between geographic areas with greatest and least burden for each CVRF were significant in all cases $(P<.0001)$. By order of size, these prevalence ratios were 1.76 for hypercholesterolemia, 1.53 for DM, 1.34 for obesity, 1.33 for smoking, and 1.19 for hypertension. 
Table 4. Adjusted Prevalences of the Different Cardiovascular Risk Factors in the Total Population and by Large Geographic Areas

\begin{tabular}{|c|c|c|c|c|c|c|}
\hline & North $(n=2431)$ & $\begin{array}{l}\text { Mediterranean } \\
\quad(\mathrm{n}=5260)\end{array}$ & $\begin{array}{c}\text { Center } \\
(n=7678)\end{array}$ & $\begin{array}{l}\text { South-East } \\
(n=4360)\end{array}$ & $\begin{array}{l}\text { Total Adjusted } \\
\text { Prevalences }^{\mathrm{a}}\end{array}$ & $\begin{array}{c}\text { Prevalence Ratios } \\
\quad(95 \% \mathrm{CI})^{\mathrm{b}}\end{array}$ \\
\hline Smoking $(n=19654)$ & $25.7(21-30.4)$ & $28.8(27-30.6)$ & $33.6(31.6-35.6)$ & $34.2(32.4-36)$ & $32.2(31.1-33.2)$ & $1.33(1.21-1.46)$ \\
\hline Obesity $(\mathrm{n}=19729)$ & $26.8(23-30.5)$ & $19.9(18.7-21.2)$ & $24.2(22.9-25.6)$ & $26.5(25-28)$ & $22.8(22.1-23.5)$ & $1.34(1.22-1.48)$ \\
\hline Diabetes $(n=16240)$ & $5.1(3.8-6.5)$ & $7.8(7.1-8.5)$ & $6(5.4-6.6)$ & $6.3(5.5-7)$ & $6.2(5.9-6.6)$ & $1.53(1.25-1.86)$ \\
\hline $\begin{array}{l}\text { Hypercholesterolemia } \\
(\mathrm{TC}>250 \mathrm{mg} / \mathrm{dL}) \\
(\mathrm{n}=15713)\end{array}$ & $17.8(14.8-20.8)$ & $20(18.7-21.3)$ & $17.1(16-18.2)$ & $12.7(11.7-13.8)$ & $17.1(16.4-17.7)$ & $1.57(1.42-1.74)$ \\
\hline $\begin{array}{l}\text { Hypercholesterolemia } \\
(\mathrm{TC}>200 \mathrm{mg} / \mathrm{dL}) \\
(\mathrm{n}=15713)\end{array}$ & $49.7(44.2-55.2)$ & $54.8(52.5-57.1)$ & $49.9(47.9-52)$ & $31.2(29.6-32.9)$ & $46.7(45.7-47.8)$ & $1.76(1.64-1.87)$ \\
\hline $\begin{array}{l}\text { Hypertension }(n=19 \\
729)\end{array}$ & $37.8(34-41.5)$ & $35.2(33.6-36.7)$ & $36.6(34.8-37.8)$ & $42(40-44)$ & $37.6(36.7-38.4)$ & $1.19(1.11-1.27)$ \\
\hline
\end{tabular}

TC indicates total cholesterol; CI, confidence interval.

a Adjusted by the direct method using the Spanish population in 2006 as the standard population.

${ }^{\mathrm{b}}$ Prevalence ratio calculated using the lowest value for each factor as the reference value

\section{Discussion}

The basic questions raised by this study are how valid is pooling individual data from participants in different studies for a single evaluation of CVRFs and to what extent can the findings of the different studies be considered as applicable to Spain as a whole?

The homogeneity of the results among studies suggests that it is legitimate to pool their individual data, and this pooling clearly increases the statistical power and precision of the estimators, in turn contributing to better internal validity of the studies. This represents an advantage with respect to estimates made by metaanalyses, in which the unit of analysis is each study instead of each individual. In addition to pooling of individual data, this can provide knowledge of the mean values of each of the CVRFs for each age group, sex, and geographic area considered.

This study provides an estimate of the prevalence according to age, sex, and large geographic areas, of the main CVRFs in the Spanish population, with an objective measure of these factors in almost 20000 subjects. The findings of our study reveal a high prevalence of modifiable CVRFs in the Spanish population, and specifically indicate that $38 \%$ of the Spanish population suffers from hypertension, 32\% smokes (37\% of men and $13 \%$ of women), $23 \%$ is obese, and $17 \%$ has TC levels greater than $250 \mathrm{mg} / \mathrm{dL}$ and $47 \%$ has levels greater than $200 \mathrm{mg} / \mathrm{dL}$, and $6 \%$ suffers from diabetes. These figures are similar to those of other neighboring countries, ${ }^{23,24}$ and seem to be in line with other previous analyses of the Spanish population. ${ }^{8}$ Some of these results are worthy of comment.

Our study confirms a high prevalence of hypertension in the Spanish population, and this prevalence is even higher than that found in the metaanalysis by Medrano et al. ${ }^{8}$ This increased prevalence of hypertension becomes accentuated in older individuals, being as high as $74 \%$ in women and $66 \%$ in men, and is very similar to that found in other studies in elderly populations. ${ }^{25,26}$ The distribution of systolic BP and diastolic BP according to age also agrees with the observations of other studies. Whereas diastolic BP increases up to middle age and then starts to decrease, systolic BP continues to increase linearly with age. $^{27}$ The increase in systolic BP with age is more marked in women, particularly those aged over 65 years, thereby explaining the greater prevalence of isolated systolic BP in these women compared to elderly men.

The prevalence of hypercholesterolemia (with a cutoff for $\mathrm{TC}>250 \mathrm{mg} / \mathrm{dL}^{19}$ ) is very similar to that found in other Spanish studies. ${ }^{8}$ In a country like Spain, with a relatively low incidence of ischemic heart disease, and where TC seems to have a lower attributable fraction, it may make more sense to consider hypercholesterolemia according to several cutoffs, as too strict a definition $(200 \mathrm{mg} / \mathrm{dL}) \mathrm{might}$ not reflect the real situation in a population such as the Spanish one. In fact, when we use a cutoff of $200 \mathrm{mg} / \mathrm{dL}$, the prevalence almost triples. In addition, the mean levels of TC in the middle-aged adult population in all the areas considered, except the South- East, exceed this value. As the population ages, the mean concentrations of TC increase, particularly in women. Age also seems to invert the differences observed between sexes, both with regard to mean values of TC as the prevalence of hypercholesterolemia. With regard to the geographic distribution, the south-east area is noteworthy for the lower frequency of hypercholesterolemia, lower levels of TC, and higher levels of HLD-C, all of which may be linked to nutritional factors. ${ }^{28}$ 
Smoking is clearly more frequent in men than in women, follows a north-south gradient, and declines with age, thereby confirming findings reported in other studies. ${ }^{29,30}$ The prevalence obtained in this study is similar to that of the metaanalysis of Medrano et $\mathrm{al}^{8}(33 \%)$ and also agrees with that of the Spanish National Health Survey ${ }^{31}$ of 1997.

Also of note is the high prevalence of obesity, above all in women. This prevalence is greater than that reported in other studies such as the one by Medrano et al. ${ }^{8}$ The prevalence of obesity increases with age ${ }^{32}$ and stabilizes after 65 years, although the differences between sexes are accentuated from this time on, a finding also observed in other studies performed in Spain. ${ }^{33}$

The prevalence of obesity is higher in the South-East than in the North, where indices of excess weight are also higher in the younger population. Over the years, several studies have observed a tendency towards higher BMI and higher rates of obesity in Spain, ${ }^{34}$ although these rates are still below those reported for the American population. ${ }^{35}$ If this increasing tendency towards obesity is confirmed, this will imply an increase in the attributed mortality, which in Spain is estimated to be around 28000 deaths per year. ${ }^{36}$ The prevalence of DM in Spain is estimated to be $6.2 \%$ for those aged between 30 and 65 years, and $10 \%$ for those aged between 30 and 89 years. ${ }^{37}$ In our study, the prevalence in the group aged 20 to 64 years $(6 \%)$ coincides with that estimated by Goday between the ages of 30 and 64 years, and it is also very similar (9\%) if the population over 65 years is included. Differences are also observed in the prevalence of diabetes by geographic area, and of note is the highest rate in the Mediterranean area, which also shows mean blood glucose values greater than those of other areas analyzed. The high percentage of high blood glucose levels in fasting conditions observed in the male population over 45 years in the Mediterranean might be, in itself, an indicator of prediabetic states and of increased cardiovascular risk. $^{38}$

With regard to the second question considered, this study was not designed to estimate the national prevalence of each of the different CVRFs investigated. To answer such a question, a study of national scope would have to be designed with standardized methods. In our analysis, we only aimed to analyze whether the geographic differences in the prevalence and distribution of the CVRFs could explain the geographic differences observed in the incidence and mortality of cardiovascular disease among regions. ${ }^{39}$ In Spain, a north-south and west-east pattern of cardiovascular mortality has been described ${ }^{40}$ and, according to the most recent data from the Municipal Mortality Atlas of the Carlos III Health Institute, ${ }^{41}$ Extremadura, Andalusia, and Levante are geographic areas where the risk of death from ischemic heart disease is greater. The IBERICA study, carried out in different Spanish provinces, also showed that there was a certain north-south gradient in the incidence and lethality of ischemic heart disease. $^{42}$ To explain these regional differences with our results, we might highlight the higher prevalence of smoking, higher levels of systolic BP, and high rates of obesity and excess weight in the south-east area, which would confirm that observed in other studies that describe a similar pattern for the south-east area. To explain this pattern, it is also necessary to take into account the high prevalence of diabetes and hypercholesterolemia reported in the Mediterranean area. Nevertheless, it is necessary to consider that the different CVRFs may interact synergistically, such that the cardiovascular risk derived from simultaneous exposure to several factors at once is greater than might be derived from the simple sum of the corresponding risks of each factor.

The present study has certain limitations that should be taken into account. This study pooled data from different studies and so has certain limitations associated with such an analysis, particularly in terms of quality of data, which depends on each of the individual studies included. Specifically, the results should be analyzed with care for the variables and subgroups of age and sex indicated in which significant heterogeneity am ong the studies was observed. Likewise, the estimate of the prevalence of certain disorders, such as hypercholesterolemia in those aged over 65 years, depends essentially on a single study (EPICARDIAN), which measured cholesterol levels in the older population. Similarly, although the criteria for classification used were the same, the measures were done by different investigators, devices, and laboratories, and so certain variability could have been introduced into the estimates that cannot be quantified. However, this study provides a measure of the population frequency taking into account the geographic area. In this sense, we should remember the limitation that not all geographic areas are equally represented in the study and that the distribution by age reflects an older population. This could affect to a certain extent the estimate, but not the trends described or the differences observed. Thus, the main contribution of this study is that, until present, data on the frequency and distribution of CVRFs in the Spanish population were not known with sufficient precision, either because broad samples of the population were not available, such as the studies of clinical examinations, or because an objective measure of the risk factors was missing such as is the case with the official health surveys. Finally, the data from the metaanalysis based on pooling estimators summarized for each study, without pooling or analysis of the individual data of the participants, are subject to substantial heterogeneity and show large discrepancies in the diagnostic criteria used. In contrast, this study provides a unified diagnostic criterion 
for each of the factors analyzed and includes data from almost 20000 individuals recruited in different population-based studies performed in Spain between 1992 and 2001. Compared to the metaanalysis of Medrano et $\mathrm{al}^{8}{ }^{8}$ it is therefore less heterogeneous because of the methodological similarities of the studies included and a precise estimate (narrower CI) of the prevalence of the CVRFs, as the analysis is based on pooling individual data and not on summarized data from the studies. In addition, the data were analyzed more exhaustively, with calculation of the mean values, and an assessment of how these changed with age, sex, and geographic area. The metaanalysis of Medrano et al, on the other hand, focussed only on estimating the prevalence of CVRFs by sex for the overall Spanish population, and did not consider data by age groups.

In short, we can conclude that in Spain the prevalence of the main CVRFs is probably high and similar to that observed in neighboring European countries. The prevalence of obesity, hypertension, hypercholesterolemia, and DM tends to increase with age, and the increase is more evident in women. Smoking, in contrast, is more prevalent at younger ages and tends to decrease significantly after 45 years of age. The geographic differences observed in the extent and distribution of these risk factors might help explain the differences in the pattern of incidence and mortality due to ischemic heart disease reported in Spain.

\section{Acknowledgments}

We would like to thank Ana Isabel Ortega for her assistance in drafting the manuscript and Eva MartínezRenedo for the additional statistical analyses performed. We also thank Francisco Fernández-Avilés (coordinator of the RECAVA network) and Pedro Luis Sánchez (Secretary of the Executive Committee of RECAVA) for revising the manuscript and for improvements suggested

\section{References}

1. Defunciones según la causa de muerte. Avance de resultados 2005. Madrid: Instituto Nacional de Estadística [cited 10 Jun 2007]. Available from: http://www.ine.es/inebase/index.html. . .

2. P Magnus, R Beagleohole. The real contribution of the major risk factors to the coronary epidemics. Arch Intern Med, 61 (2001), pp. 2657-2660.

3. PM Ridker. Evaluating novel cardiovascular risk factors. Ann Intern Med, 130 (1999), pp. 933-937. 4. JG Canto, AE Iskandrian. Major risk factors for cardiovascular disease. Debunking the only 50\% myth. JAMA, 290 (2003), pp. 947-949.

5. P Greenland, MD Knoll, J Stamler, JD Neaton, AR Dyer, DB Garside, et al. Major risk factors as antecedent of fatal and nonfatal coronary heart disease events. JAMA, 290 (2003), pp. 891-897.

6. UN Khot, MB Khot, CT Bajzer, SK Sapp, EM Ohman, SJ Brener, et al. Prevalence of conventional risk factors in patients with coronary heart disease. JAMA, 290 (2003), pp. 898-904.

7. S Yusuf, S Hawken, S Ounpuu, T Dans, A Avezum, F Lanas, et al. Effect of potentially modifiable risks factors associated with myocardial infarction in 52 countries (the INTERHEART study): case-control study. Lancet, 364 (2004), pp. 937-952.

8. MJ Medrano, E Cerrato, R Boix, M Delgado-Rodríguez. Factores de riesgo cardiovascular en la población española: metaanálisis de estudios transversales. Med Clin (Barc), 124 (2005), pp. 606-612.

9. C Suárez, C del Arco, T Sáez, F Blanco, JM Ruiz, M Alonso, et al. Monitorización ambulatoria de la presión arterial en ancianos. Estudio EPICARDIAN. Rev Esp Cardiol, 51 (1998), pp. 965-971.

10. B Balkau, MA Charles, T Drivsholm, K Borch-Johnsen, N Wareham, JS Yudkin, et al. European Group for the Study of Insulin Resistance (EGIR). The frequency of the who metabolic syndrome in european cohorts, and an alternative definition of an insulin resistance syndrome. Diabetes Metab, 28 (2002), pp. 364-376.

11. JR Banegas. Epidemiología de la hipertensión arterial en personas mayores de 60 años en España, Anales de la Real Academia Nacional de Medicina, Madrid (2002), pp. 143-151. .

12. R Masiá, A Pena, J Marrugat, J Sala, J Vila, M Pavesi, et al. High prevalence of cardiovascular risk factors in Gerona, Spain, a province with low myocardial infarction incidence. REGICOR Investigators. J Epidemiol Community Health, 52 (1998), pp. 707-715.

13. B Rodríguez Panos, C Sanchis, F García Gosalvez, JA Divison, LM Artigao, J López Abril, et al. Prevalencia de diabetes mellitus y su asociación con otros factores de riesgo cardiovascular en la provincia de Albacete. Grupo de Enfermedad Vascular de Albacete (GEVA). Aten Primaria, 25 (2000), pp. 166-171.

14. Fragosos Segura, Mery Grius. Factores de riesgo cardiovascular en una población rural de Castilla-La Mancha. Rev Esp Cardiol, 52 (1999), pp. 577-588. .

15. MJ Tormo, C Navarro, MD Chirlaque, D Perez. Factores de riesgo cardiovascular en la Región de Murcia, España. Rev Esp Salud Pública, 71 (1997), pp. 515-529. .

16. F Rigo, G Frontera, J Llobera, T Rodríguez, I Borras, E Fuentespina. Prevalencia de factores de riesgo cardiovascular en las Islas Baleares (estudio CORSAIB). Rev Esp Cardiol, 58 (2005), pp. 1411-1419. . .

17. AV Chobanian, GL Bakris, HR Black, WC Cushman, LA Green, Jr Izzo JL, the National High Blood Pressure Education Program Coordinating Committee, et al. The Seventh Report of the Joint National Committee on 
Prevention, Detection, Evaluation, and Treatment of High Blood Pressure. The JNC 7 Report. JAMA, 289 (2003), pp. 2560-2572.

18. American Diabetes Association. Report of the Expert Committee on the diagnosis and classification of diabetes mellitus. Diabetes Care, 26 (Suppl 1) (2003), pp. 5-20.

19. Executive Summary of the Third Report of the National Cholesterol Education Program (NCEP) Expert Panel on Detection, Evaluation, and Treatment of High Blood Cholesterol in Adults (Adult Treatment Panel III). JAMA, 285 (2001), pp. 2486-2497.

20. Measuring obesity-Classification and description of anthropometric data. Report on a WHO Consultation on the epidemiology of obesityWHO, Copenhague (1988). .

21. Guidelines for controling and monitoring the tobacco epidemicWHO Tobacco or Health Programme, Geneva (1997).

22. Demografía y población. Revisión del padrón municipal 2006. Datos a nivel nacional, comunidad autónoma y provincia. Población por edad (año a año) y sexo [cited 15 Nov 2007]INE, Madrid (2007) Available from: http://www.ine.es/inebase/cgi/axi.

23. K Kuuslasmaa, H Tunsdall-Pedoe, A Dobson, S Fortmann, S Sans, H Tolonen, for the WHO MONICA Project, et al. Estimation of contribution of changes in classic risk factors to trends in coronary-event rates across the WHO MONICA Project populations. Lancet, 355 (2000), pp. 675-687.

24. K Wolf-Maier, R Cooper, JR Banegas, S Giampaoli, H Hans-werner, M Joffres, et al. Hypertension prevalence and blood pressure level in 6 European countries, Canada and the United States. JAMA, 289 (2003), pp. 2363 2369.

25. MJ Belza, J Quiroga, F Beland, MV Zunzunegui. La hipertensión en las personas ancianas: prevalencia, conocimiento, tratamiento y control. Aten Primaria, 19 (1997), pp. 367-371.

26. C Suárez, C Del Arco, T Sáez, F Blanco, JM Ruiz, M Alonso, et al. Monitorización ambulatoria de la presión arterial en ancianos. Estudio EPICARDIAN. Rev Esp Cardiol, 51 (1998), pp. 965-971.

27. A Coca. Control de la hipertensión arterial en España. Resultado del estudio Controlpress 95 . Hipertensión, 12 (1995), pp. 182-188.

28. MI Covas. Olive oil and the cardiovascular system. Pharmacol Res, 55 (2007), pp. 175-186.

29. A Fernández, A Schiaffino, M García, E Salto, JR Villalbí, JM Borras. Prevalencia del consumo de tabaco en España entre 1945 y 1995. Reconstrucción a partir de las Encuestas Nacionales de Salud. Med Clin (Barc), 120 (2003), pp. 14-16. . .

30. J Bellido Casado, JC Martín Escudero, A Dueñas Laita, FJ Mena Martí, D Arzua Mouronte, F Simal Blanco. Hábito tabáquico en una población general: descripción de la prevalencia, grado de consolidación y fase de abandono. Arch Bronconeumol, 37 (2001), pp. 75-80

31. Encuesta Nacional de Salud de España 1997Ministerio de Sanidad y Consumo, Madrid (1999). . .

32. J Aranceta, LL Serra, M Foz, B Moreno. Prevalencia de obesidad en España. Med Clin (Barc), 125 (2005), pp. $460-466 . .$.

33. JL Gutiérrez-Fisac, E López-García, JL Banegas, A Graciani Pérez-Regadera, F Rodríguez-Artalejo. Prevalence of overweight and obesity in Spain: cross-sectional study of a national sample of persons aged 60 and over. Obes Res, 12 (2004), pp. 710-715.

34. H Schroder, R Elosua, J Vila, H Marti, MI Covas, J Marrugat. Secular trends of obesity and cardiovascular risk factors in a Mediterranean population. Obesity (Silver Spring), 15 (2007), pp. 557-562.

35. CL Odien, MD Carroll, LR Curtin, MA McDowell, CJ Tabak, KM Flegal. Prevalence of overweight and obesity in the United States, 1999-2004. JAMA, 295 (2006), pp. 1549-1555. .

36. JR Banegas, E López García, Jl Gutiérrez-Fisac, P Guallar-Castillón, F Rodríguez Artalejo. A simple estimate of mortality attributable to excess weight in the European Union. Eur J Clin Nutr, 57 (2003), pp. 201-208.

37. A Goday. Epidemiología de la diabetes y sus complicaciones no coronarias. Rev Esp Cardiol, 55 (2002), pp. 657670.

38. SM Haffner, MP Stern, HP Hazuda, BD Mitchell, JK Patterson. Cardiovascular risk factors in confirmed prediabetic individuals. Does the clock for coronary heart disease start ticking before the onset of clinical diabetes?. JAMA, 263 (1990), pp. 2893-2898.

39. J Marrugat, R Elosua, E Aldasoro, MJ Tormo, H Vanaclocha, A Segura, et al. Regional variability in population acute myocardial infarction cumulative incidente and mortality rates in Spain 1997 and 1998. Eur J Epidemiol, 19 (2004), pp. 831-839.

40. F Rodríguez Artalejo, Jr Banegas Banegas, P Guayar Castillón, E López García, M Puente Mendizábal, J Del Rey Calero. Distribución geográfica de las enfermedades cardiovasculares en España: la mortalidad es mayor en las regiones del sur y del mediterráneo. Cardiovascular Risk Factors, 9 (2000), pp. 311-318. . .

41. Atlas Municipal de Mortalidad por cáncer y otras causas en España (1989-1998). Madrid: Instituto de Salud Carlos III [cited 15 Nov 2007]. Available from: http://www.iscii.es/htdocs/centros/epidemiología/libros/Atlasmunicipal.pdf. .

42. R Elosua, M Fiol, MJ Tormo, A Segura, J Bregada, M Villegas, en nombre del grupo IBERICA, et al. Letalidad poblacional del infarto agudo de miocardio en cuatro regiones españolas. Estudio IBERICA. Rev Esp Cardiol, 52 (1999), p. 91. 